\title{
Regulation of GDF-15, a distant TGF- $\beta$ superfamily member, in a mouse model of cerebral ischemia
}

\author{
Katharina Schindowski • Oliver von Bohlen und Halbach • Jens Strelau • \\ Dirk A. Ridder • Oliver Herrmann • Andreas Schober • Markus Schwaninger • \\ Klaus Unsicker
}

Received: 28 October 2010 / Accepted: 4 November 2010 /Published online: 3 December 2010

(C) The Author(s) 2010. This article is published with open access at Springerlink.com.

\begin{abstract}
GDF-15 is a novel distant member of the TGF- $\beta$ superfamily and is widely distributed in the brain and peripheral nervous system. We have previously reported that GDF-15 is a potent neurotrophic factor for lesioned dopaminergic neurons in the substantia nigra, and that GDF-15-deficient mice show progressive postnatal losses of motor and sensory neurons. We have now investigated the regulation of GDF-15 mRNA and immunoreactivity in
\end{abstract}

This work was supported by the German Research Foundation (DFG): grant Un34/23-1.

\section{K. Schindowski}

Institute for Pharmaceutical Biotechnology,

University of Applied Science Biberach,

Biberach/Riß, Germany

O. von Bohlen und Halbach

Department of Anatomy \& Cell Biology,

University of Greifswald,

Greifswald, Germany

J. Strelau

Interdisciplinary Center for Neurosciences \& Department of

Neuroanatomy, University of Heidelberg,

Heidelberg, Germany

D. A. Ridder $\cdot$ M. Schwaninger

Department of Pharmacology, University of Heidelberg,

Heidelberg, Germany

\section{O. Herrmann}

Department of Neurology, University of Heidelberg,

Heidelberg, Germany

A. Schober $\cdot$ K. Unsicker $(\square)$

Department of Molecular Embryology, Institute of Anatomy \&

Cell Biology, University of Freiburg,

Albertstrasse 17,

79104, Freiburg, Germany

e-mail: ku39@anat.uni-freiburg.de the murine hippocampal formation and selected cortical areas following an ischemic lesion by occlusion of the middle cerebral artery (MCAO). MCAO prominently upregulates GDF-15 mRNA in the hippocampus and parietal cortex at $3 \mathrm{~h}$ and $24 \mathrm{~h}$ after lesion. GDF-15 immunoreactivity, which is hardly detectable in the unlesioned brain, is drastically upregulated in neurons identified by double-staining with NeuN. NeuN staining reveals that most, if not all, neurons in the granular layer of the dentate gyrus and pyramidal layers of the cornu ammonis become GDF-15-immunoreactive. Moderate induction of GDF-15 immunoreactivity has been observed in a small number of microglial cells identified by labeling with tomato lectin, whereas astroglial cells remain GDF-15-negative after MCAO. Comparative analysis of the size of the infarcted area after MCAO in GDF-15 wild-type and knockout mice has failed to reveal significant differences. Together, our data substantiate the notion that GDF-15 is prominently upregulated in the lesioned brain and might be involved in orchestrating post-lesional responses other than the trophic support of neurons.

Keywords Growth/differentiation factor-15.

Expression - Hippocampus - Cortex - Occlusion of the middle cerebral artery - Ischemia · GDF-15 knockout .

Mouse (adult, male, C57BL/6)

\section{Introduction}

Stroke is the third most common cause of death in industrialized countries. Despite intense research efforts, there is still no advisable therapy for most patients (Kidwell et al. 2001; Schäbitz and Fisher 2006). Neurotrophins and growth factors with a capacity to promote the 
survival and regeneration of lesioned neurons have been proposed as useful for the treatment of cerebral ischemia. Their protective potential in ischemic lesions has been shown in a variety of in vitro and animal model studies (Kawamata et al. 1997; Ma et al. 2001; Schäbitz and Fisher 2006; Schäbitz et al. 2001; Song et al. 2002; Sugimori et al. 2001; Wagner et al. 1999). Even so, the transfer of trophic molecules from the bench to the clinic is still in its infancy, involves many still unresolved problems, such as modes of delivery, and may include unexpected draw-backs, as previously shown for fibroblast growth factor-2 (FGF-2; Bogousslavsky et al. 2002).

A major obstacle in the development of rational therapies for stroke is the lack of a coherent understanding of the primary and secondary molecular scenarios elicited by the ischemic insult. This also applies to the still incomplete picture of the lesion-mediated regulation of growth factors; this is of particular importance in light of the accumulating evidence for the multiple synergies and contextual actions of many growth factors (cf. Peterziel et al. 2002).

Growth/differentiation factor-15 (GDF-15) is a novel member of the transforming growth factor (TGF)- $\beta$ superfamily and has been cloned and characterized in our and several other laboratories (Böttner et al. 1999a, b; Strelau et al. 2000b); it is identical to macrophageinhibitory cytokine-1 (MIC-1; Bauskin et al. 2000; Bootcov et al. 1997; Fairlie et al. 1999), which is found in macrophages, and to some other published sequences (Hromas et al. 1997; Lawton et al. 1997; YokoyamaKobayashi et al. 1997). GDF-15/MIC-1 is widely expressed by many epithelia of exocrine glands, e.g., the prostate, salivary, and mammary glands, in the placenta, airways, liver, intestinal epithelia, and in the S3 segment of nephrons (Böttner et al. 1999b). Its functions at these locations are enigmatic. In macrophages, GDF-15/MIC-1 is induced by proinflammatory cytokines such as tumor necrosis factor (TNF)- $\alpha$, interleukin (IL)-1 $\beta$, and IL-6, but not by interferon (IFN) $-\gamma$ and lipopolysaccharide (Bootcov et al. 1997).

We have previously shown that GDF-15 is a potent neurotrophic factor in vitro and in vivo for embryonic and lesioned midbrain dopaminergic neurons (Strelau et al. 2000b). Analysis of the knockout has revealed progressive postnatal losses of motoneurons in the hindbrain and spinal cord, together with sensory neuron losses (Strelau et al. 2009). GDF-15 is dramatically upregulated in cryolesioned cortical neurons (Schober et al. 2001) and has also been shown to prevent the death of potassium-deprived cerebellar granule neurons by activating Akt and inhibiting constitutively active extracellular signal-regulated kinase (Subramaniam et al. 2003).
We show now that GDF-15 is upregulated in hippocampal and cortical neurons following the occlusion of the middle cerebral artery (MCAO) in mice; this further corroborates the notion that GDF-15 is a lesion-induced factor. Comparative analysis of the size of the infarcted area in GDF-15 wild-type and knockout mice has failed to reveal significant differences suggesting that GDF-15 is involved in orchestrating post-lesional responses other than the trophic support of neurons.

\section{Materials and methods}

\section{Surgical procedures for MCAO}

Adult male C57BL/6 mice (25-35 g) were used throughout this study. To induce a transient MCAO, mice were anesthetized with $1 \%$ Halothane in $33 \% \quad \mathrm{O}_{2}$ and $66 \%$ $\mathrm{N}_{2} \mathrm{O}$. Rectal temperature was monitored continuously and maintained at $37 \pm 0.5^{\circ} \mathrm{C}$ by external heating. For laser Doppler measurements, the probe (P403; Perimed, Järfälla, Sweden) was placed $3 \mathrm{~mm}$ lateral and $6 \mathrm{~mm}$ posterior to the Bregma. Relative perfusion units were measured. The left carotid region was exposed through a midline skin incision. A 5-0 nylon suture (Ethilon, Norderstedt, Germany) with a blunted tip was inserted into the external carotid artery and advanced into the internal carotid until the laser Doppler signal decreased considerably. The suture was removed after 15 min unless indicated otherwise. In sham-operated mice no suture was inserted. After $3 \mathrm{~h}$ up to 9 days of reperfusion, mice were deeply anesthetized (Rompun/ Ketanest), and perfused brains were removed. The neurological status of the mice was assessed according to Bederson et al. (1986). Contralateral motor deficits of the upper limb were considered as an effect of MCAO. Infarct volumes were determined after an occlusion time of $30 \mathrm{~min}$. To measure the infarct size, we deeply reanesthetized mice and perfused them intracardially with Ringer solution at $24 \mathrm{~h}$ after surgery. The procedure for infarct detection by silver staining of coronal cryosections, quantification, and edema correction was as previously described (Herrmann et al. 2005).

To induce permanent MCAO (Table 1), mice were anesthetized by intraperitoneal injection of $150 \mu \mathrm{l} 2.5 \%$ tribromoethanol per $10 \mathrm{~g}$ body weight. The left MCA was exposed through a burr hole and occluded by microbipolar coagulation as described previously (Herrmann et al. 2005). At $48 \mathrm{~h}$ after permanent MCAO, infarct volumes were determined and corrected for brain edema as previously described (Lin et al. 1993). All animal experiments were performed in accordance with German animal rights regulations and with permission of the Regierungspräsidium Karlsruhe, Germany. 
Immunohistochemistry

A polycolonal antibody against a specific peptide sequence (HRTDSGVSLQTYDDL) of the C-terminus of the GDF-15 protein was raised in rabbit by Dr. J. Pineda (FZB Biotechnik GmbH, Berlin, Germany) and characterized as described (Schober et al. 2001). Coronal paraffin-embedded sections ( $4 \mu \mathrm{m}$ thickness) were stained with this polyclonal antibody in phosphate-buffered saline (PBS). A biotinylated secondary antibody against rabbit IgG was detected by using streptavidin coupled to $\mathrm{Cy}-2$ and $\mathrm{Cy}-3$ (purchased from Vector Labs), respectively, as indicated. Neurons were identified by staining with $\alpha$ neuron-specific nuclear protein $(\alpha-\mathrm{NeuN}$; Santa Cruz, USA), GFAP ${ }^{+}$-astrocytes by staining for glial fibrillary acidic protein (GFAP; Sigma, Germany), and microglial cells by staining with tomato lectin (Sigma). Sections were counterstained with the nuclear dye 4,6-diamidino-2phenylindole (DAPI; Sigma).

\section{In situ hybridization}

Mice were perfused with saline followed by $4 \%$ paraformaldehyde (PFA). Brains were removed, postfixed overnight at $4^{\circ} \mathrm{C}$, and then placed in $30 \%$ sucrose for cryoprotection, prior to being frozen on dry ice. Cryosections $(20 \mu \mathrm{m})$ were cut on a cryostat and mounted on Superfrost slides. Non-radioactive in situ hybridization on cryosections and the preparation of digoxigenin-labeled probes for mouse GDF-15 were carried out as previously described (Ernsberger et al. 1997). Mouse GDF-15 (bp: 713-1392, accession code AF159571) was cloned from adult mouse brain cDNA by the polymerase chain reaction (PCR) by using a pGEMT vector system (Promega) following the manufacturer's instructions. The plasmid was appropriately linearized and transcribed with SP6 and T7 for the antisense probe and sense control, respectively.

\section{Reverse transcription with PCR}

Ischemic brain tissue consisting of the ipsilateral hippocampal formation and thalamus and the ipsilateral ischemic cortex (all between Bregma $+0.1 \mathrm{~mm}$ and $-2.8 \mathrm{~mm}$ ) were prepared from saline-perfused brains and immediately frozen on dry ice. Tissue was homogenized under liquid nitrogen, and RNA was extracted with Tri-Fast (PeqLab, Germany). Synthesis of cDNA was performed with $1 \mu \mathrm{g}$ total RNA, reverse transcriptase from Moloney murine leukemia virus, and oligo$\mathrm{dT}_{18}$ (all purchased from New England Labs, Germany). For qualitative PCR, equal amounts of cDNA were used in a group of PCRs with a set of primers to amplify $\beta$-actin (5'-primer: 5'-TCAT GAAGTGTGACGTTGACATCCGT3' 3'-primer: 5'-CCTA GAAGCATTTGCGGTGCACGATG-3') as a house-keeping-gene and a set of primers to amplify GDF-15 (5'-primer: 5'-CCGAGAGGACTCGAACTCAG-3' 3' - primer: 5' - TAAGAACCACCGGGGTGTAG-3'). For quantitative PCR, serial dilutions of cDNA were amplified in parallel with primers

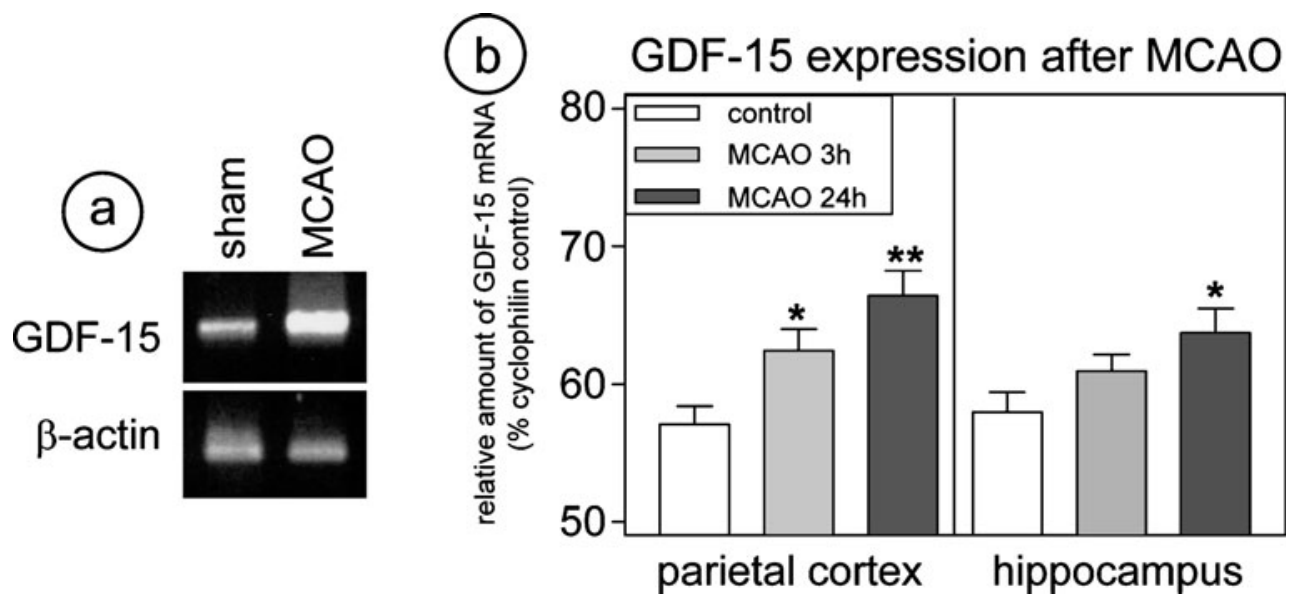

Fig. 1 Growth/differentiation factor-15 (GDF-15) is prominently upregulated in the ipsilateral hippocampal formation and parietal cortex following transient occlusion of the middle cerebral artery $(M C A O)$. a Upregulation of GDF-15 mRNA relative to $\beta$-actin in the ipsilateral hippocampal formation at $3 \mathrm{~h}$ after MCAO and sham surgery, respectively. b Quantification of GDF-15 mRNA relative to the housekeeping gene cyclophilin (set as $100 \%$ ) reveals a progressive

increase in the parietal cortex and hippocampus at 3 and $24 \mathrm{~h}$, respectively. Parietal cortex: sham control, $57.06 \pm 1.35 \% ; 3$ h reperfusion, $62.4 \pm 1.55 \%$; $24 \mathrm{~h}$ reperfusion $66.4 \pm 1.80 \%$. Hippocampus: sham control, $58.0 \pm 1.45 \%$; $3 \mathrm{~h}$ reperfusion, $60.94 \pm 1.23 \%$; $24 \mathrm{~h}$ reperfusion, $63.69 \pm 1.78 \%$. $* P<0.05, * * P<0.01 \quad v s$. control, respectively). The means \pm SEM of three independent experiments are shown 
for cyclophilin (5'-primer: 5'-ACCCCACC GTGTTCTTCGAC-3'; 3'-primer: 5'-CATTTGCCATGGA CAAGATG- $\left.3^{\prime}\right)$ as internal standards and GDF-15 (5'primer: 5'-GGCTGCATGCCAACCA-3'; 3'-primer: 5'-
TCTCA CCTCTGGACTGAGTATTCC-3') with the SYBR-Green-Kit (PE Biosystems, Germany) in a GeneAmp-Cycler equipped with GeneAmp 5700SDS software.
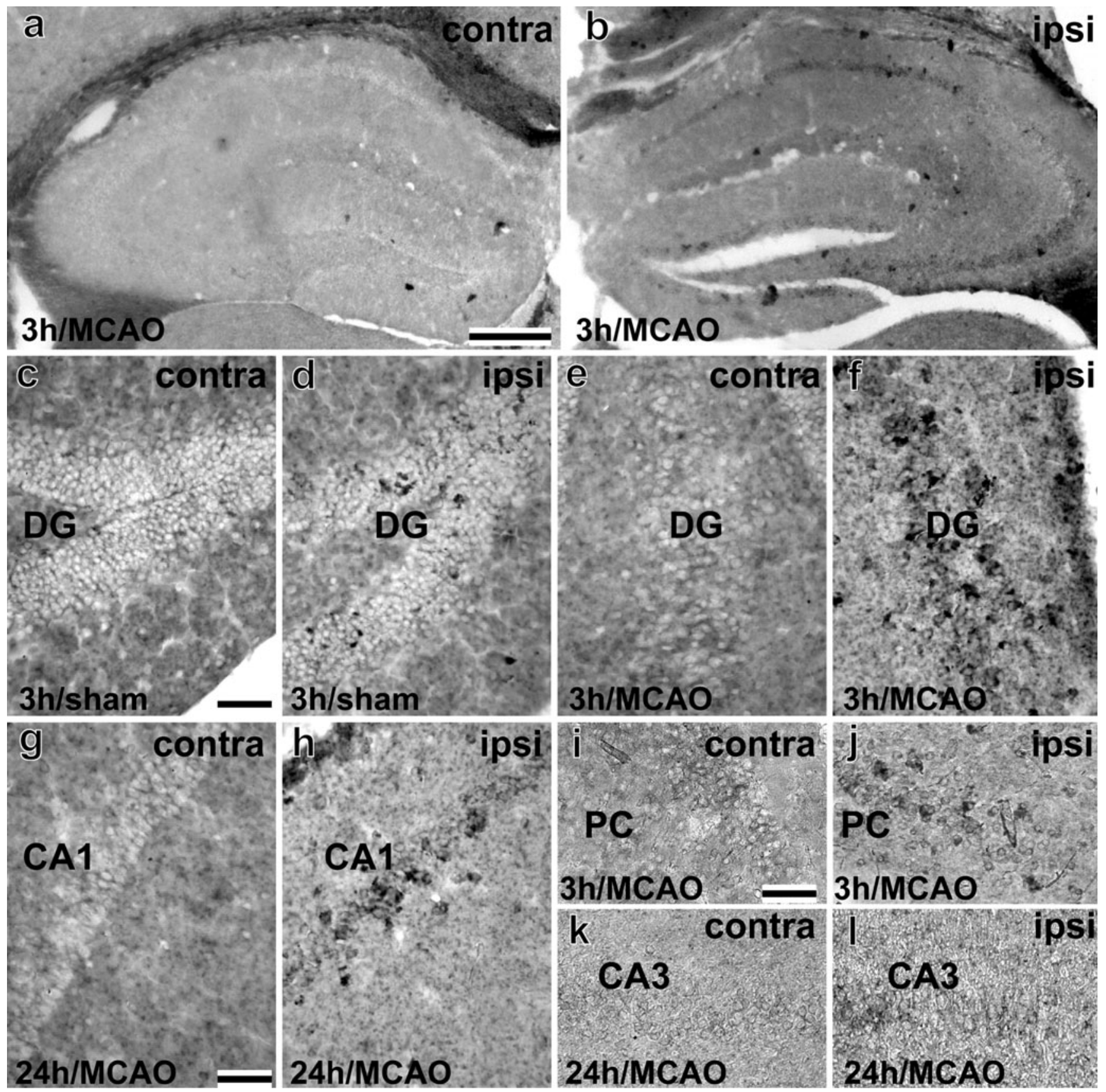

Fig. 2 GDF-15 mRNA revealed by in situ hybridization is increased in the hippocampal formation and retrosplenial/motor cortex of the ipsilateral hemisphere following transient occlusion of the middle cerebral artery $(M C A O)$. a, b Comparison of the hippocampal formation of the contralateral (contra) and ipsilateral (ipsi) hemisphere reveals a substantial increase in GDF-15 mRNA signals on the MCAO-lesioned side at $3 \mathrm{~h}$ after reperfusion. c-f Higher magnifica-

tions of the dentate gyrus $(D G)$ illustrating that GDF-15 is sparse, if detectable, in sham-operated animals (c, d) and contralateral to the lesion (e) but is robustly induced in granule cells at $3 \mathrm{~h}$ on the ipsilateral side (f). GDF-15 mRNA is also distinctly increased in the $\mathrm{CA} 1(\mathbf{g}, \mathbf{h})$ and $\mathrm{CA} 3(\mathbf{k}, \mathbf{l})$ regions and in the retrosplenial/motor cortex $(P C$ piriform cortex) on the side ipsilateral to the lesion $(\mathbf{i}, \mathbf{j})$. Bars $200 \mu \mathrm{m}(\mathbf{a}, \mathbf{b}), 50 \mu \mathrm{m}(\mathbf{c}-\mathbf{h}), 25 \mu \mathrm{m}(\mathbf{k}, \mathbf{l})$ 


\section{Results}

GDF-15 is upregulated in the ischemic core following transient $\mathrm{MCAO}$

As a variety of TGF- $\beta$ superfamily members have been shown to be prominently upregulated following neural lesions (cf. Kiefer et al. 1995), and as GDF-15 has been shown to be upregulated in neurons following a cryolesion of the rat cortex (Schober et al. 2001), we first explored the putative regulation of GDF-15 after transient MCAO by reverse transcription with PCR (RTPCR). As shown in Fig. 1a, GDF-15 mRNA was prominently upregulated in the ipsilateral hippocampal formation by $3 \mathrm{~h}$ after MCAO, whereas in sham-operated mice, GDF-15 was expressed at levels comparable with control mice. Figure $1 \mathrm{~b}$ shows the clear and timedependent progressive increase of GDF-15 transcripts in the parietal cortex and hippocampus ipsilateral to the lesion after $3 \mathrm{~h}$ and $24 \mathrm{~h}$, respectively. At $48 \mathrm{~h}$ after cerebral ischemia, GDF-15 mRNA was significantly decreased (data not shown).
GDF-15 mRNA is increased in the hippocampal formation and retrosplenial/motor cortex of the ipsilateral hemisphere as early as $3 \mathrm{~h}$ post-MCAO

We next analyzed the cellular distribution of GDF-15 mRNA following transient MCAO. Figure 2 shows the hippocampus contralateral (Fig. 2a) and ipsilateral (Fig. 2b) to the ischemic lesion at $3 \mathrm{~h}$ after re-perfusion. At this time point, GDF-15 mRNA was not detectable on the non-ischemic side corroborating our previous findings (cf. Schober et al. 2001; Strelau et al. 2000a) showing that unlesioned adult neurons express low or undetectable levels of GDF-15 mRNA. On the ipsilateral side, a majority of cells within the band of pyramidal neurons in the CA1 through CA3 regions and the majority of cells in the dentate gyrus (DG) expressed detectable amounts of GDF-15 mRNA. This is illustrated at higher magnification in Fig. 2c-f showing that GDF-15 mRNA is only sporadically observed or is absent from granule cells in the DG in sham-operated animals (Fig. 2c, d) and contralateral to the lesion (Fig. 2e) but is robustly induced in numerous granule cells at $3 \mathrm{~h}$ on the ipsilateral side (Fig. 2f). Similarly, GDF-15 mRNA was distinctly increased
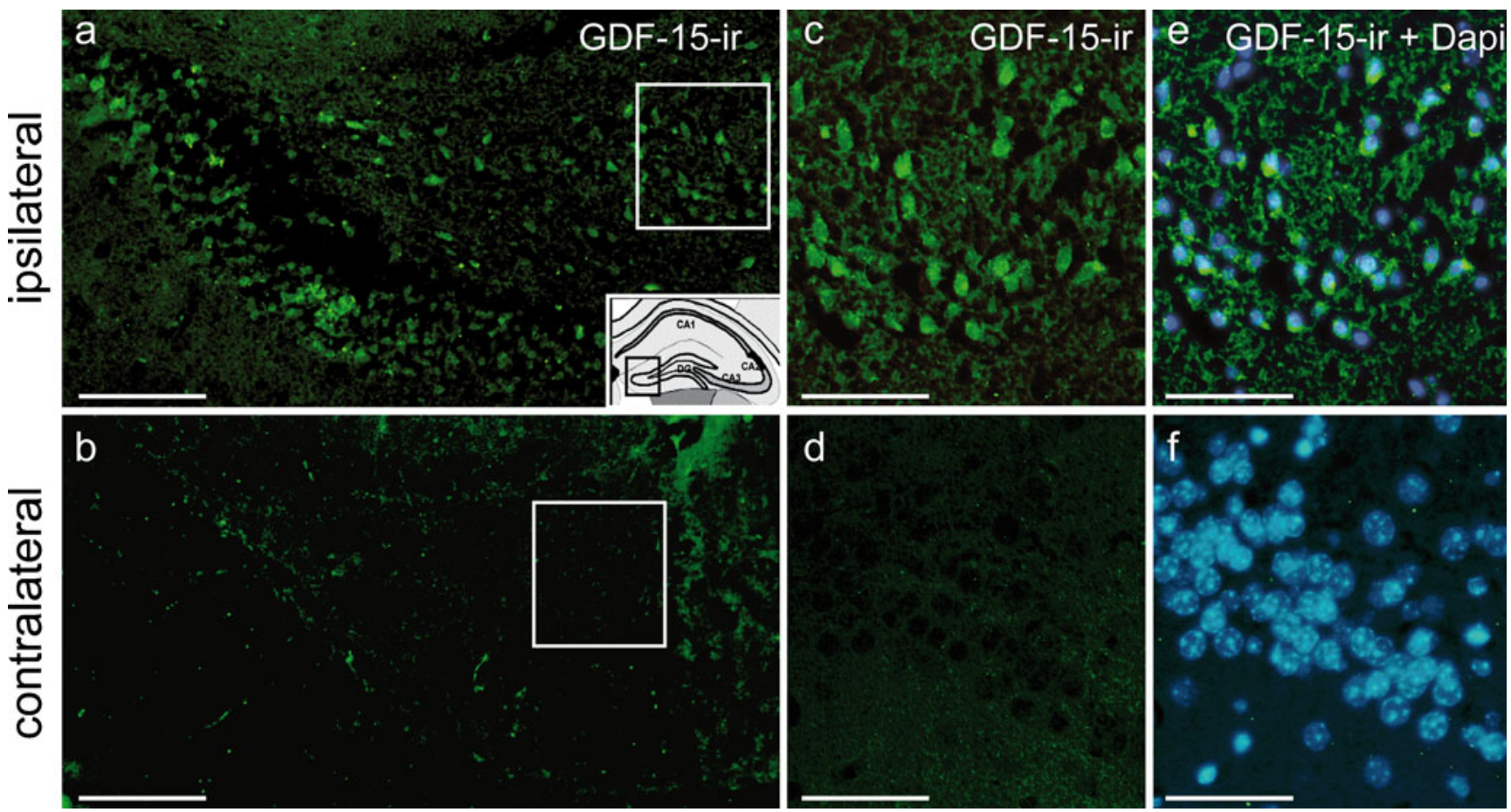

Fig. 3 Transient MCAO raises levels of GDF-15 immunoreactivity $(G D F-15-i r)$ in the DG. a, b Increased GDF-15 immunoreactivity in the ischemic DG at $24 \mathrm{~h}$ (a), as compared with the contralateral side (b), which hardly reveals any GDF-15 immunoreactivity. Inset in a Representation of the brain area studied showing the region (small boxed area) viewed in a ( $D G$ dentate gyrus). c Higher magnification of large boxed area in a. GDF-15 immunoreactivity is observed in nearly all cells in the ischemic DG. e Overlay with the nuclear dye DAPI (Dapi) reveals that about $90 \%$ of all detectable cells in the DG show GDF-15 immunoreactivity by $24 \mathrm{~h}$ after MCAO. d, f In the nonischemic contralateral DG, no or sporadic immunostaining for GDF15 can be seen. d Higher magnification of boxed area in b. Bars $200 \mu \mathrm{m}(\mathbf{a}, \mathbf{b}), 100 \mu \mathrm{m}(\mathbf{c}-\mathbf{f})$ 
in neurons of the CA1 and CA3 region, illustrated for the $24 \mathrm{~h}$ time point in Fig. 2g, h, k, 1. As shown in Fig. 2i, j, cells in the retrosplenial/motor cortex, viz., layer II/III ipsilateral to the lesion, also upregulated GDF-15 mRNA. Generally, the induction of GDF-15 mRNA was still evident at $48 \mathrm{~h}$ after the ischemic insult, although levels seemed to be substantially decreased as compared with those at $24 \mathrm{~h}$ (not shown). Together, these data suggest that transient MCAO elicits a rapid and significant increase in GDF-15 mRNA expression in two representative areas of the forebrain, viz., the hippocampal formation and retrosplenial/motor cortex.

GDF-15 immunoreactivity is increased in the hippocampus and cerebral cortex of the ipsilateral hemisphere following transient MCAO

Next, we investigated whether the increase in GDF-15 mRNA was followed by an increase in GDF-15 protein, detected through GDF-15 immunoreactivity. Figure 3a demonstrates GDF-15 immunoreactivity in cells of the DG on the lesioned side by $24 \mathrm{~h}$ after reperfusion. In confirmation of previous results that had failed to demonstrate detectable levels of GDF-15 immunoreactivity in unlesioned neurons (Schober et al. 2001; Strelau et al. 2000a), GDF-15 immunoreactivity in the contralateral DG was below detectability. To obtain more information related to the proportion of GDF-15immunoreactive cells, we performed double-staining for GDF-15 protein and DAPI. As shown in Fig. 3c, e for the ipsilateral DG and in Fig. 3d, f for the contralateral DG, most cells in the DG ipsilateral to the transient MCAO were positive for GDF-15 protein within $24 \mathrm{~h}$ after reperfusion, whereas GDF-15 immunoreactivity was virtually absent on the contralateral side. Figure 4 reveals that, in addition to occurring in the DG (Fig. 4a), GDF-15 immunoreactivity was also induced in the ipsilateral piriform cortex (Fig. 4c) and the hippocampal CA2 region (Fig. 4e) by $24 \mathrm{~h}$ after reperfusion. The corresponding contralateral sides exhibited only scarce GDF-15 immunostaining. By 48 h, GDF-15 immunoreactivity was clearly decreased and had become undetectable after 9 days (not shown). We therefore conclude that MCAOmediated changes in GDF-15 expression levels imply the induction of both mRNA and protein.

GDF-15 is predominantly expressed by neurons subsequent to MCAO

We next aimed at identifying the types of neural cells exhibiting elevated levels of GDF-15 after transient MCAO by using

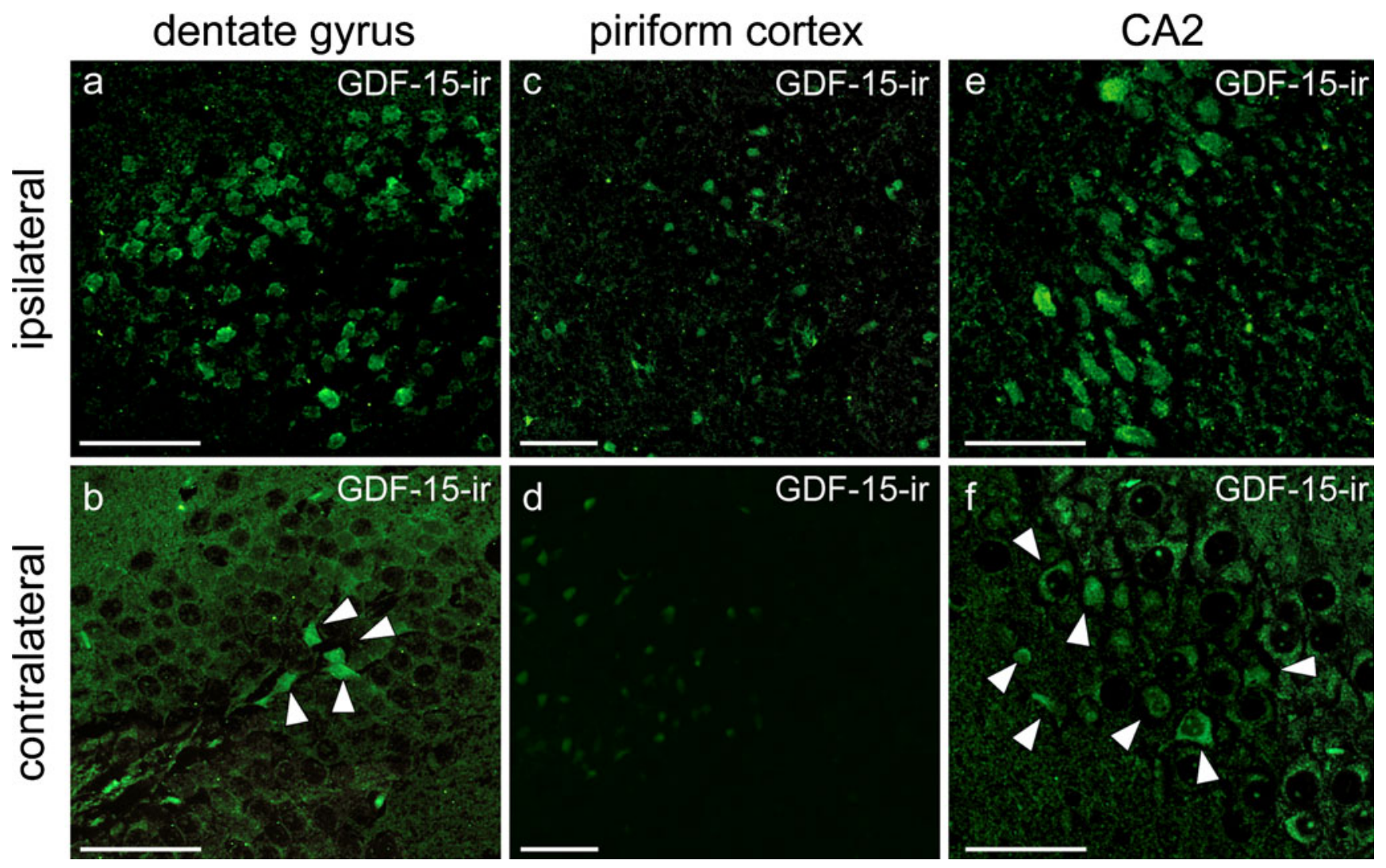

Fig. 4 As in the DG (a, b), GDF-15 immunoreactivity (GDF-15-ir) is also increased in the piriform cortex (c, d) and CA2 region $(\mathbf{e}, \mathbf{f})$ at 24 $\mathrm{h}$ subsequent to transient MCAO. In the non-lesioned hemisphere, only a few cells (arrowheads) display GDF-15 immunoreactivity (b, d, f). Bars $100 \mu \mathrm{m}$ 
Table 1 Infarct volumes in growth/differentiation factor-15 knockout $(G D F-15 \mathrm{ko})$ and wild-type control mice. No statistically significant difference was noted between the genotypes ( $t$-test). The transient occlusion of the middle cerebral artery $(M C A O)$ lasted $30 \mathrm{~min}$. Values are expressed as means \pm SEM

\begin{tabular}{lll}
\hline Measured parameter & Wild-type controls & GDF-15 ko mice \\
\hline Transient MCAO & & \\
Neuroscore & $1.1 \pm 0.6$ & $1.4 \pm 0.6$ \\
Infarct volume $\left(\mathrm{mm}^{3}\right)$ & $16.9 \pm 1.8(n=7)$ & $15.6 \pm 0.6(n=6)$ \\
Permanent MCAO & & \\
Infarct volume $\left(\mathrm{mm}^{3}\right)$ & $17.9 \pm 3.0(n=5)$ & $18.8 \pm 5.4(n=5)$ \\
\hline
\end{tabular}

markers specific for neurons (NeuN), astroglia (GFAP), and microglia (tomato lectin). Figure 5 shows GDF-15 (Fig. 5a, d) and NeuN (Fig. 5b, e) immunoreactivity together with DAPI staining (Fig. 5c, f, g) and respective merged images (Fig. 5c, g) in the DG (Fig. 5a-c) and CA3 (Fig. $5 \mathrm{~d}-\mathrm{g}$ ) region on the side ipsilateral to the ischemic lesion at $24 \mathrm{~h}$ after re-perfusion. Clearly, most if not all NeuN-positive cells are also positive for GDF-15 suggesting that a significant proportion of GDF-15 is apparently localized in neurons. As shown in Fig. 6a-d, GDF-15 immunoreactivity is apparently not associated with GFAPpositive astrocytes. Labeling with tomato lectin as a marker for macrophages/microglial cells (Fig. 6e-h) revealed occasional cells that were double-labeled with tomato lectin and for GDF-15. Together, these data corroborate the notion that neurons are a predominant site of GDF-15 upregulation following an ischemic lesion.

Comparison in GDF-15 wild-type and knockout mice fails to reveal significant differences in the size of the infarcted area following transient or permanent MCAO

To evaluate the effect of GDF-15 on the lesion size, we subjected GDF-15 knockout mice and wild-type controls to a transient 30-min MCAO and measured the neurological deficit and the infarct size at $24 \mathrm{~h}$ after MCAO. The genotypes differed neither in the infarct size nor in the neurological deficit (Table 1). Moreover, in a model of permanent MCAO, which leads to predominantly cortical infarcts, the infarct size was unaffected by the GDF-15 deficiency (Table 1).
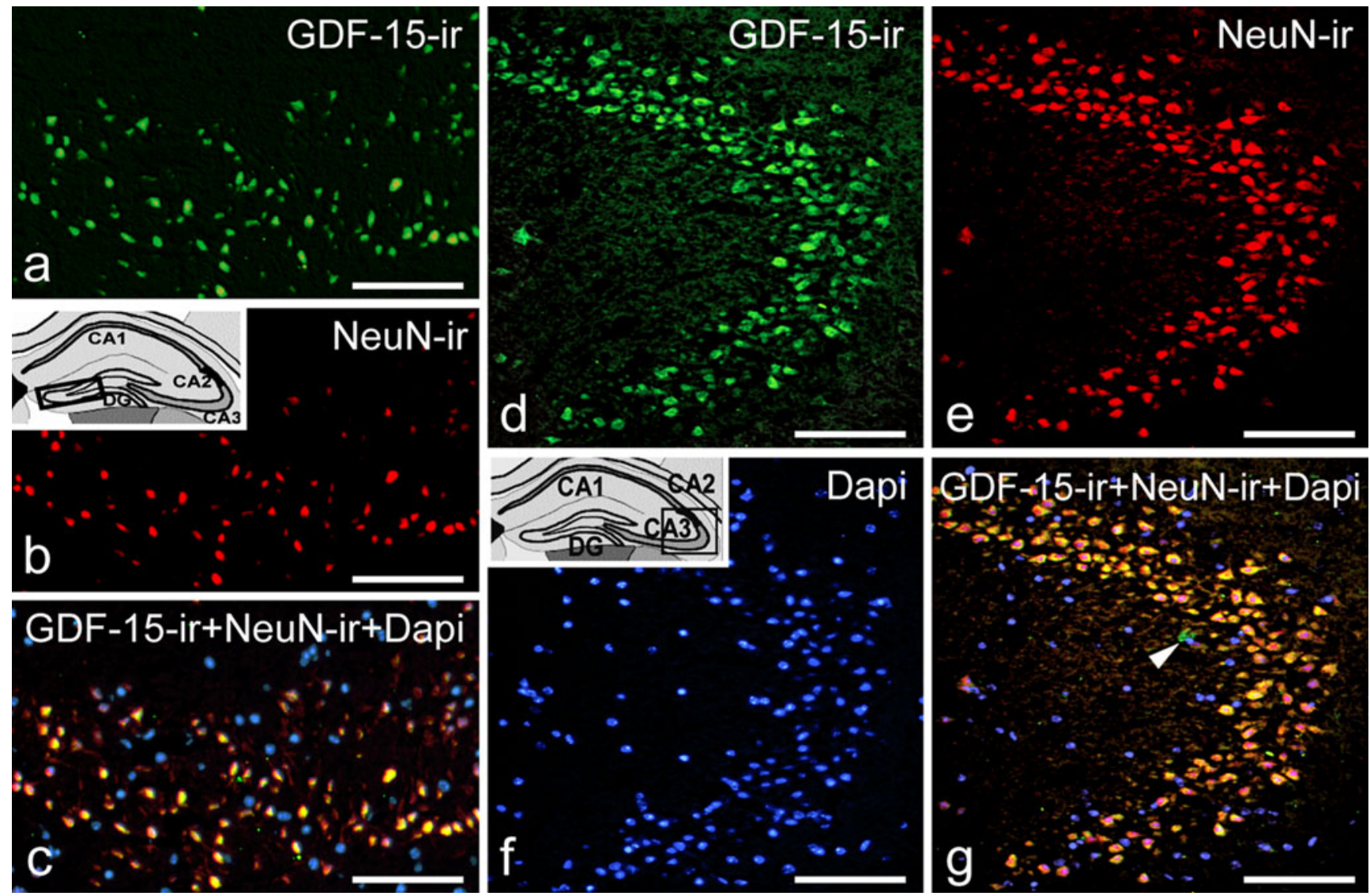

Fig. 5 GDF-15 immunoreactivity (GDF-15-ir) is predominantly found in neurons subsequent to transient MCAO as revealed by NeuN co-labeling. DG $(\mathbf{a}-\mathbf{c})$, CA3 $(\mathbf{d}-\mathbf{g})$. Insets in $\mathbf{b}, \mathbf{d}$ Representa- tions of brain regions studied (boxed areas regions shown in micrographs). Bars $200 \mu \mathrm{m}(\mathbf{a}-\mathbf{c}), 100 \mu \mathrm{m}(\mathbf{d}-\mathbf{g})$ 

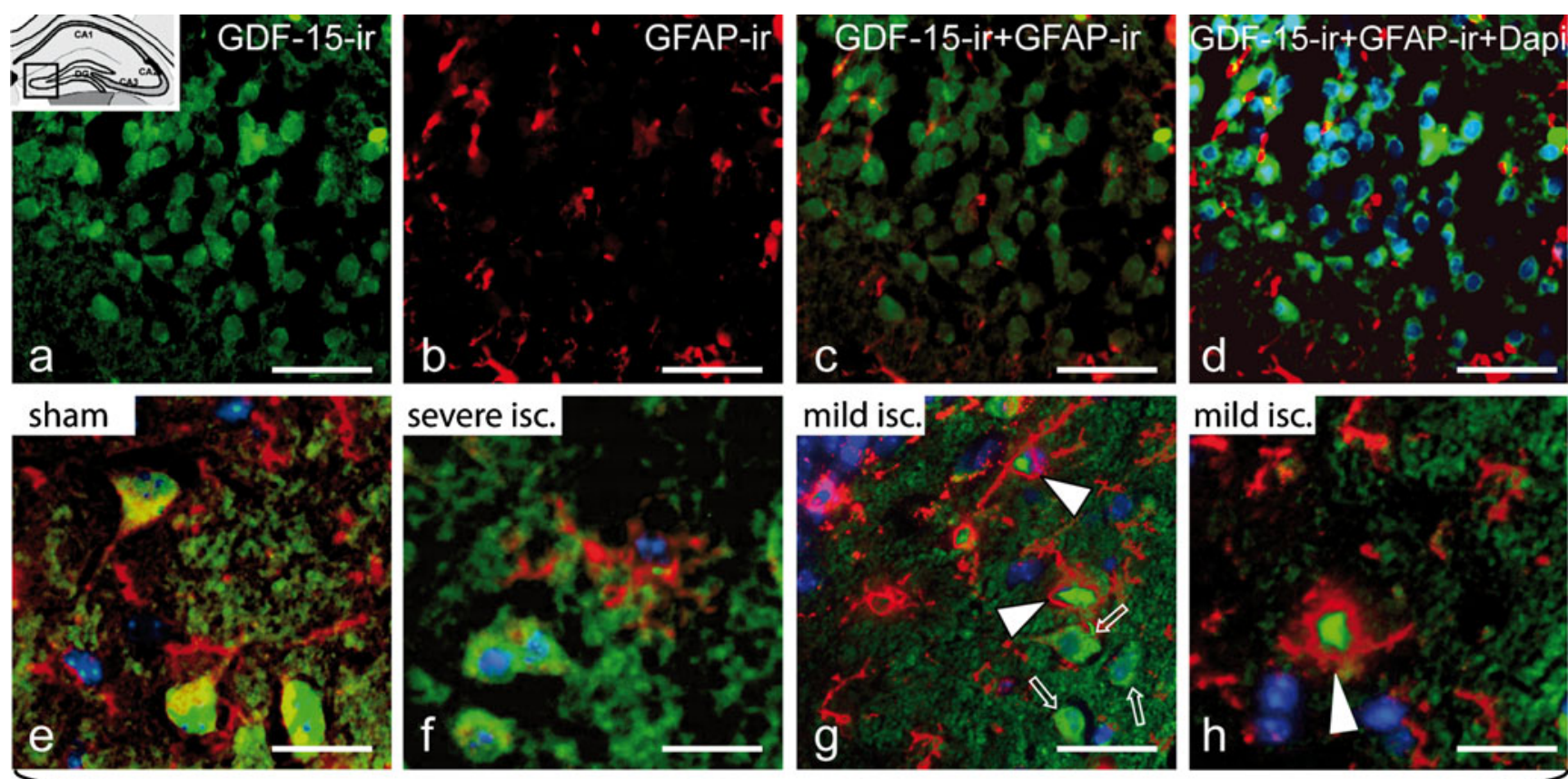

\section{GDF-15-ir+Tomato Lectin+Dapi}

Fig. 6 GDF-15 in astroglial and microglial cells. Transient MCAO (isc. ischemia) did not induce GDF-15 immunoreactivity (GDF-15-ir) in astrocytes labeled with an antibody to glial fibrillary acidic protein (GFAP; a-d) but did induce GDF-15 immunoreactivity in scattered

\section{Discussion}

The results of the present study allow GDF-15, a novel member of the TGF- $\beta$ superfamily, to be added to the list of growth factors and cytokines that play a role in ischemic brain lesion (Buisson et al. 2003; Harvey et al. 2005; Lykissas et al. 2007; Wu 2005). GDF-15 was discovered in our laboratory by searching expressed sequence tag databases for conserved structural hallmarks of TGF- $\beta$ s (Böttner et al. 1999a, 1999b). Independently, the gene was also cloned by several other groups in the search for genes involved in (1) macrophage activation (MIC-1; Bootcov et al. 1997; Fairlie et al. 1999), (2) placental functions (placental bone morphogenetic protein; Hromas et al. 1997), and (3) anti-inflammatory functions (non-steroidal anti-inflammatory drug activated gene 1; Baek et al. 2001). The rat, mouse, and human genes of GDF-15 that we have isolated by screening of genomic libraries are all composed of two exons and contain a single intron that interrupts the coding sequences at identical positions within the prepro-domain of the corresponding proteins. The predicted proteins contain the structural hallmarks of members of the TGF- $\beta$ superfamily, including the seven conserved carboxy-terminal cysteine residues that form the cystine knot. GDF-15 is synthesized as a large precursor molecule, which is cleaved to yield the biologically active mature protein. Expression of the proteases involved has not been studied in microglial cells labeled with tomato lectin (e-h; arrows, arrowheads). Inset in a Representation of the region studied in $\mathbf{a}-\mathbf{h}$ (boxed area). Bars $25 \mu \mathrm{m}(\mathbf{a}-\mathbf{d}), 20 \mu \mathrm{m}(\mathbf{g}), 10 \mu \mathrm{m}(\mathbf{e}, \mathbf{f}, \mathbf{h})$

sufficient detail. The orthologous molecules show the lowest sequence conservation of all members of the TGF- $\beta$ superfamily (Böttner et al. 1999b).

Most groups studying GDF-15 have focused on its putative functions in various pathologies and cancer. These include such diverse roles as, e.g., GDF-15 as a biomarker for p53 pathway activation (Yang et al. 2003), serum concentrations of GDF-15 as a predictor of miscarriage (Tong et al. 2004), its identification as a novel downstream target of the AKT/ GSK-3beta pathway (Yamaguchi et al. 2004), and its proapoptotic role in prostate cancer cells (Liu et al. 2003) and many other cancer cell types. With well over 300 publications on GDF-15 (medline: gdf15 or gdf-15) to date, the lack of any in-depth analyses of its physiological functions in cell-biological contexts and in organs in which it is highly and specifically expressed and localized is surprising. Interestingly, in the context of our present study, two companion articles (Kempf et al. 2006; Xu et al. 2006) have reported that GDF-15 is a cardioprotective factor that is rapidly upregulated in cardiomyocytes on ischemia/reperfusion and during other cardiovascular events triggering oxidative stress, including pressure overload, heart failure, and atherosclerosis. Together with our data on the regulation of GDF-15 in brain lesions, this suggests that GDF-15 can act as a lesion-induced factor in other systems that counteract the consequences of lesioning. The receptor(s) for GDF-15 is 
unknown and possibly not a member of the TGF- $\beta$ and glialcell-derived neurotrophic factor (GDNF) receptor families.

Although GDF-15 is widely and prominently expressed in many injured organs and exocrine glands, in liver, lung, placenta, and kidney, (cf. Böttner et al. 1999a), its levels of expression in the adult rat and mouse central nervous system (CNS) are relatively low (Schober et al. 2001; Strelau et al. 2000b). The site with the highest expression level is the choroid plexus, from which GDF-15 is secreted into the cerebrospinal fluid. Although GDF-15 mRNA and protein can be detected by RT-PCR and immunoblotting in every region of the unlesioned brain studied (Strelau et al. 2000b), expression levels are apparently below detectability by in situ hybridisation and immunohistochemistry. However, in the neonatal brain, GDF-15 can be found outside the choroid plexus, in the ventricular and subventricular layers of the striatum (Schober et al. 2001).

Brain lesions profoundly alter GDF-15 expression. This has been documented in a previous study in which we have investigated the regulation of GDF-15 mRNA and protein following cryolesion of the rat cortex (Schober et al. 2001). Since GDF-15 is highly expressed by macrophages (Fairlie et al. 1999; Schlittenhardt et al. 2004), a rise in expression was primarily expected for microglial cells. Interestingly, this was not the case, and neurons close to the lesion site, but also neurons presumably projecting to the lesioned area, were identified as the predominant site of the observed rise in GDF-15 mRNA and protein following the cryolesion (Schober et al. 2001).

The present study, which involves the use of an entirely unrelated CNS lesion paradigm, further supports the notion that neurons, rather than microglia, are the predominant site of the upregulation of GDF-15 subsequent to lesion. The significance of this upregulation is enigmatic as yet but might be sought in relation to a role in rescuing neurons or in executing cell death. Several members of the TGF- $\beta$ family, but also non-TGF- $\beta$ s, have been implicated in performing dual roles in activating survival and death pathways in neurons, depending on the activation of specific sets of receptors and the contextual presence of other growth factors. For example, TGF- $\beta$ can not only promote the survival of midbrain dopaminergic neurons in vitro and in vivo (Farkas et al. 2003; Krieglstein et al. 1995), but also, when neutralized in vivo, prevent programmed neuron death suggesting a pro-apoptotic function (Krieglstein et al. 2000). This also applies to GDF-15, for which anti- and proapoptic roles have been described (Baek et al. 2001; Liu et al. 2003; Strelau et al. 2000b; Subramaniam et al. 2003). TGF$\beta$ is well established as requiring additional factors for its neurotrophic actions, such as FGF-2 (Krieglstein et al. 1998c), GDNF (Krieglstein et al. 1998b; Schober et al. 1999, 2007), ciliary neurotrophic factor and neurotrophins (Krieglstein et al. 1998a). Whether this also applies to its pro-apoptotic roles is not known. With regard to GDF-15, any putative synergisti- cally acting molecules, if required, still need to be identified. The molecular basis of the synergy of TGF- $\beta$ with GDNF has been elucidated in greater detail. TGF- $\beta$ apparently has the capacity to increase the insertion of a lipid-anchored coreceptor of GDNF, viz., GFR $\alpha 1$, into the plasma membrane (Peterziel et al. 2002, 2007), thereby enabling GDNF to activate its compound receptor GFR $\alpha 1$ and c-ret. Whether similar mechanisms are also activated by GDF-15 as a putative synergistic partner remain to be investigated. Thus, as shown in the present study, the expression of GDF-15 elicited in lesioned neurons is not overtly indicative of their protection or of the activation of death pathways. Although the infarct size in the GDF-15 knockout mice is not clearly different from that in GDF-15 wild-type mice, future studies using GDF-15 deficient mice (Strelau et al. 2009) can be expected to assign more detailed roles to GDF-15 in the orchestration of responses to brain lesions, possibly with prospects for using it as a target for therapeutic strategies.

Acknowledgement We thank Ulla Hinz, Nicole Karch, and Elisabeth Specht-Delius for skilful technical assistance.

Open Access This article is distributed under the terms of the Creative Commons Attribution Noncommercial License which permits any noncommercial use, distribution, and reproduction in any medium, provided the original author(s) and source are credited.

\section{References}

Baek SJ, Horowitz JM, Eling TE (2001) Molecular cloning and characterization of human nonsteroidal anti-inflammatory drugactivated gene promoter. Basal transcription is mediated by $\mathrm{Sp} 1$ and Sp3. J Biol Chem 276:33384-33392

Bauskin AR, Zhang HP, Fairlie WD, He XY, Russell PK, Moore AG, Brown DA, Stanley KK, Breit SN (2000) The propeptide of macrophage inhibitory cytokine (MIC-1), a TGF-beta superfamily member, acts as a quality control determinant for correctly folded MIC-1. EMBO J 19:2212-2220

Bederson JB, Pitts LH, Tsuji M, Nishimura MC, Davis RL, Bartkowski H (1986) Rat middle cerebral artery occlusion: evaluation of the model and development of a neurologic examination. Stroke 17:472-476

Bogousslavsky J, Victor SJ, Salinas EO, Pallay A, Donnan GA, Fieschi C, Kaste M, Orgogozo JM, Chamorro A, Desmet A (2002) Fiblast (trafermin) in acute stroke: results of the European-Australian phase II/III safety and efficacy trial. Cerebrovasc Dis 14:239-251

Bootcov MR, Bauskin AR, Valenzuela SM, Moore AG, Bansal M, He XY, Zhang HP, Donnellan M, Mahler S, Pryor K, Walsh BJ, Nicholson RC, Fairlie WD, Por SB, Robbins JM, Breit SN (1997) MIC-1, a novel macrophage inhibitory cytokine, is a divergent member of the TGF-beta superfamily. Proc Natl Acad Sci USA 94:11514-11519

Böttner M, Laaff M, Schechinger B, Rappold G, Unsicker K, SuterCrazzolara C (1999a) Characterization of the rat, mouse, and human genes of growth/differentiation factor-15/macrophage inhibiting cytokine-1 (GDF-15/MIC-1). Gene 237:105-111

Böttner M, Suter-Crazzolara C, Schober A, Unsicker K (1999b) Expression of a novel member of the TGF-beta superfamily, growth/differentiation factor-15/macrophage-inhibiting cytokine-1 (GDF-15/MIC-1) in adult rat tissues. Cell Tissue Res 297:103-110 
Buisson A, Lesne S, Docagne F, Ali C, Nicole O, MacKenzie ET, Vivien D (2003) Transforming growth factor-beta and ischemic brain injury. Cell Mol Neurobiol 23:539-550

Ernsberger U, Patzke H, Rohrer H (1997) The developmental expression of choline acetyltransferase (ChAT) and the neuropeptide VIP in chick sympathetic neurons: evidence for different regulatory events in cholinergic differentiation. Mech Dev 68:115-126

Fairlie WD, Moore AG, Bauskin AR, Russell PK, Zhang HP, Breit SN (1999) MIC-1 is a novel TGF-beta superfamily cytokine associated with macrophage activation. J Leukoc Biol 65:2-5

Farkas LM, Dunker N, Roussa E, Unsicker K, Krieglstein K (2003) Transforming growth factor-beta(s) are essential for the development of midbrain dopaminergic neurons in vitro and in vivo. $\mathrm{J}$ Neurosci 23:5178-5186

Harvey BK, Hoffer BJ, Wang Y (2005) Stroke and TGF-beta proteins: glial cell line-derived neurotrophic factor and bone morphogenetic protein. Pharmacol Ther 105:113-125

Herrmann O, Baumann B, Lorenzi R de, Muhammad S, Zhang W, Kleesiek J, Malfertheiner M, Kohrmann M, Potrovita I, Maegele I, Beyer C, Burke JR, Hasan MT, Bujard H, Wirth T, Pasparakis M, Schwaninger M (2005) IKK mediates ischemia-induced neuronal death. Nat Med 11:1322-1329

Hromas R, Hufford M, Sutton J, Xu D, Li Y, Lu L (1997) PLAB, a novel placental bone morphogenetic protein. Biochim Biophys Acta $1354: 40-44$

Kawamata T, Katayama Y, Maeda T, Mori T, Aoyama N, Kikuchi T, Uwahodo Y (1997) Antioxidant, OPC-14117, attenuates edema formation and behavioral deficits following cortical contusion in rats. Acta Neurochir Suppl (Wien) 70:191-193

Kempf T, Eden M, Strelau J, Naguib M, Willenbockel C, Tongers J, Heineke J, Kotlarz D, Xu J, Molkentin JD, Niessen HW, Drexler H, Wollert KC (2006) The transforming growth factorbeta superfamily member growth-differentiation factor- 15 protects the heart from ischemia/reperfusion injury. Circ Res 98:351-360

Kidwell CS, Saver JL, Mattiello J, Warach S, Liebeskind DS, Starkman S, Vespa PM, Villablanca JP, Martin NA, Frazee J, Alger JR (2001) Diffusion-perfusion MR evaluation of perihematomal injury in hyperacute intracerebral hemorrhage. Neurology 57:1611-1617

Kiefer R, Streit WJ, Toyka KV, Kreutzberg GW, Hartung HP (1995) Transforming growth factor-beta 1: a lesion-associated cytokine of the nervous system. Int J Dev Neurosci 13:331-339

Krieglstein K, Suter-Crazzolara C, Fischer WH, Unsicker K (1995) TGF-beta superfamily members promote survival of midbrain dopaminergic neurons and protect them against MPP+toxicity. EMBO J 14:736-742

Krieglstein K, Farkas L, Unsicker K (1998a) TGF-beta regulates the survival of ciliary ganglionic neurons synergistically with ciliary neurotrophic factor and neurotrophins. J Neurobiol 37:563-572

Krieglstein K, Henheik P, Farkas L, Jaszai J, Galter D, Krohn K, Unsicker K (1998b) Glial cell line-derived neurotrophic factor requires transforming growth factor-beta for exerting its full neurotrophic potential on peripheral and CNS neurons. J Neurosci 18:9822-9834

Krieglstein K, Reuss B, Maysinger D, Unsicker K (1998c) Short communication: transforming growth factor-beta mediates the neurotrophic effect of fibroblast growth factor-2 on midbrain dopaminergic neurons. Eur J Neurosci 10:2746-2750

Krieglstein K, Richter S, Farkas L, Schuster N, Dunker N, Oppenheim RW, Unsicker K (2000) Reduction of endogenous transforming growth factors beta prevents ontogenetic neuron death. Nat Neurosci 3:1085-1090

Lawton LN, Bonaldo MF, Jelenc PC, Qiu L, Baumes SA, Marcelino RA, Jesus GM de, Wellington S, Knowles JA, Warburton D,
Brown S, Soares MB (1997) Identification of a novel member of the TGF-beta superfamily highly expressed in human placenta. Gene 203:17-26

Lin TN, He YY, Wu G, Khan M, Hsu CY (1993) Effect of brain edema on infarct volume in a focal cerebral ischemia model in rats. Stroke 24:117-121

Liu T, Bauskin AR, Zaunders J, Brown DA, Pankhurst S, Russell PJ, Breit SN (2003) Macrophage inhibitory cytokine 1 reduces cell adhesion and induces apoptosis in prostate cancer cells. Cancer Res 63:5034-5040

Lykissas MG, Batistatou AK, Charalabopoulos KA, Beris AE (2007) The role of neurotrophins in axonal growth, guidance, and regeneration. Curr Neurovasc Res 4:143-151

Ma J, Qiu J, Hirt L, Dalkara T, Moskowitz MA (2001) Synergistic protective effect of caspase inhibitors and bFGF against brain injury induced by transient focal ischaemia. $\mathrm{Br} \mathrm{J}$ Pharmacol 133:345-350

Peterziel H, Unsicker K, Krieglstein K (2002) TGFbeta induces GDNF responsiveness in neurons by recruitment of GFRalpha1 to the plasma membrane. J Cell Biol 159:157-167

Peterziel H, Paech T, Strelau J, Unsicker K, Krieglstein K (2007) Specificity in the crosstalk of TGFbeta/GDNF family members is determined by distinct GFR alpha receptors. J Neurochem 103:2491-2504

Schäbitz WR, Fisher M (2006) Perspectives on neuroprotective stroke therapy. Biochem Soc Trans 34:1271-1276

Schäbitz WR, Hoffmann TT, Heiland S, Kollmar R, Bardutzky J, Sommer C, Schwab S (2001) Delayed neuroprotective effect of insulin-like growth factor-i after experimental transient focal cerebral ischemia monitored with MRI. Stroke 32:12261233

Schlittenhardt D, Schober A, Strelau J, Bonaterra GA, Schmiedt W, Unsicker K, Metz J, Kinscherf R (2004) Involvement of growth differentiation factor-15/macrophage inhibitory cytokine-1 (GDF-15/MIC-1) in oxLDL-induced apoptosis of human macrophages in vitro and in arteriosclerotic lesions. Cell Tissue Res 318:325-333

Schober A, Hertel R, Arumae U, Farkas L, Jaszai J, Krieglstein K, Saarma M, Unsicker K (1999) Glial cell line-derived neurotrophic factor rescues target-deprived sympathetic spinal cord neurons but requires transforming growth factor-beta as cofactor in vivo. J Neurosci 19:2008-2015

Schober A, Böttner M, Strelau J, Kinscherf R, Bonaterra GA, Barth M, Schilling L, Fairlie WD, Breit SN, Unsicker K (2001) Expression of growth differentiation factor-15/ macrophage inhibitory cytokine-1 (GDF-15/MIC-1) in the perinatal, adult, and injured rat brain. J Comp Neurol 439:32-45

Schober A, Peterziel H, Bartheld CS von, Simon H, Krieglstein K, Unsicker K (2007) GDNF applied to the MPTP-lesioned nigrostriatal system requires TGF-beta for its neuroprotective action. Neurobiol Dis 25:378-391

Song BW, Vinters HV, Wu D, Pardridge WM (2002) Enhanced neuroprotective effects of basic fibroblast growth factor in regional brain ischemia after conjugation to a blood-brain barrier delivery vector. J Pharmacol Exp Ther 301:605-610

Strelau J, Böttner M, Lingor P, Suter-Crazzolara C, Galter D, Jaszai J, Sullivan A, Schober A, Krieglstein K, Unsicker K (2000a) GDF15/MIC-1 a novel member of the TGF-beta superfamily. J Neural Transm Suppl 60:273-276

Strelau J, Sullivan A, Böttner M, Lingor P, Falkenstein E, SuterCrazzolara C, Galter D, Jaszai J, Krieglstein K, Unsicker K (2000b) Growth/differentiation factor- $15 /$ macrophage inhibitory cytokine- 1 is a novel trophic factor for midbrain dopaminergic neurons in vivo. J Neurosci 20:8597-8603

Strelau J, Strzelczyk A, Rusu P, Bendner G, Wiese S, Diella F, Altick AL, Bartheld CS von, Klein R, Sendtner M, Unsicker K (2009) 
Progressive postnatal motoneuron loss in mice lacking GDF-15. J Neurosci 29:13640-13648

Subramaniam S, Strelau J, Unsicker K (2003) Growth differentiation factor-15 prevents low potassium-induced cell death of cerebellar granule neurons by differential regulation of Akt and ERK pathways. J Biol Chem 278:8904-8912

Sugimori H, Speller H, Finklestein SP (2001) Intravenous basic fibroblast growth factor produces a persistent reduction in infarct volume following permanent focal ischemia in rats. Neurosci Lett 300:13-16

Tong S, Marjono B, Brown DA, Mulvey S, Breit SN, Manuelpillai U, Wallace EM (2004) Serum concentrations of macrophage inhibitory cytokine 1 (MIC 1 ) as a predictor of miscarriage. Lancet 363:129-130

Wagner JP, Black IB, DiCicco-Bloom E (1999) Stimulation of neonatal and adult brain neurogenesis by subcutaneous injection of basic fibroblast growth factor. J Neurosci 19:6006-6016
Wu D (2005) Neuroprotection in experimental stroke with targeted neurotrophins. NeuroRx 2:120-128

Xu J, Kimball TR, Lorenz JN, Brown DA, Bauskin AR, Klevitsky R, Hewett TE, Breit SN, Molkentin JD (2006) GDF15/MIC-1 functions as a protective and antihypertrophic factor released from the myocardium in association with SMAD protein activation. Circ Res 98:342-350

Yamaguchi K, Lee SH, Eling TE, Baek SJ (2004) Identification of nonsteroidal anti-inflammatory drug-activated gene (NAG-1) as a novel downstream target of phosphatidylinositol 3-kinase/AKT/ GSK-3beta pathway. J Biol Chem 279:49617-49623

Yang H, Filipovic Z, Brown D, Breit SN, Vassilev LT (2003) Macrophage inhibitory cytokine-1: a novel biomarker for p53 pathway activation. Mol Cancer Ther 2:1023-1029

Yokoyama-Kobayashi M, Saeki M, Sekine S, Kato S (1997) Human cDNA encoding a novel TGF-beta superfamily protein highly expressed in placenta. J Biochem 122:622-626 